\title{
Phenomenology and Biosemiotics
}

\author{
Morten Tønnessen ${ }^{1}$ (D) Timo Maran $^{2} \cdot$ Alexei Sharov $^{3}$
}

Received: 1 November 2018 / Accepted: 25 November 2018 / Published online: 29 November 2018

(C) Springer Media B.V., onderdeel van Springer Nature 2018

Phenomenology was from the outset developed as a philosophy about human experience and its relation to logics, reality and epistemology (Husserl 1900, 1901), and has a century-long history of engagement with questions concerning the mind, consciousness, and intentionality. Phenomenology was among the first fields of study to recognize that subjectivity emerges from personal experience, a realization that was later reiterated and elaborated in existentialism, Jamesian pragmatism, constructivism, and enactivism. It appears that the methodology of biosemiotics has a clear resemblance with that of phenomenology, but with the important difference that several biosemiotic perspectives can be applied to all living organisms, rather than just to humans. Just as phenomenology, biosemiotics too explores the nature of mind, consciousness, and intentionality, but our field does this in all kinds of organisms with varying levels of complexity.

This editorial explores the relationship between phenomenology and biosemiotics and addresses four questions in the following order: (i) Are there phenomena beyond human experience? (ii) What is the relation between semiosis and phenomena? (iii) Should Biosemiotic Phenomenology be practiced as pure theory, or as applicable for empirical studies? And lastly, (iv) how can biosemiotics contribute to phenomenology?

As Herbert Spiegelberg (1982) narrates in his classical portrayal of the phenomenological movement, phenomenology is a rich and varied tradition involving competing outlooks. On a similar note, Dan Zahavi (2006: 1) remarks that "it has often been claimed that virtually all post-Husserlian phenomenologists ended up distancing themselves from most aspects of Husserl's original program" for phenomenology. Many biosemioticians, as well as other semioticians, regard the 'Phaneroscopy' of Charles Sanders Peirce as the semiotic counterpart to phenomenology. Other connections derive

Morten Tønnessen

morten.tonnessen@uis.no

1 Department of Social Studies, University of Stavanger, Nådlandsbråtet 25, 4034 Stavanger, Norway

2 Department of Semiotics, University of Tartu, Tartu, Estonia

3 Laboratory of Genetics, National Institute on Aging, Baltimore, MD, USA 
from the phenomenology of Maurice Merleau-Ponty (note e.g. the attention paid by Merleau-Ponty to the skin and seeing the world as flesh, inspiring Jesper Hoffmeyer's treatment of biological membranes in Hoffmeyer 2008: 26, cf. Westling 2014) and the biological philosophy of Hans Jonas (his ideas about the feeling and subjectivity of life have been further developed in a biosemiotic framework by Andreas Weber (2002)). In this editorial we take a different perspective, emphasizing the ways in which Umwelt theory can serve as a foundation for phenomenological studies.

\section{Are There Phenomena beyond Human Experience?}

The question as to whether or not there are phenomena beyond human experience is of foundational importance to phenomenology. Given contemporary knowledge in biology, cognitive science, and philosophy of mind, answering this question with a simple "yes" would hardly by controversial, even without any familiarity with von Uexküll's Umwelt theory. For instance, according to The Cambridge Declaration on Consciousness (Lowland et al. 2012: 2):

Convergent evidence indicates that non-human animals have the neuroanatomical, neurochemical, and neurophysiological substrates of conscious states along with the capacity to exhibit intentional behaviors. Consequently, the weight of evidence indicates that humans are not unique in possessing the neurological substrates that generate consciousness. Non-human animals, including all mammals and birds, and many other creatures $[\ldots]$, also possess these neurological substrates.

An implication of these acknowledged facts is that it is reasonable to assume that all mammals and birds, as well as "many other creatures" with relevant neurophysiological substrates, have conscious experience. However, despite such breakthroughs in recognition of consciousness in animals, current phenomenology remains predominantly anthropocentric in its perspective - as if the human species were the only species on Earth capable of having phenomena and relating to them.

The idea that a multitude of different species have their own kind of phenomenological world, tailor-made to fit the biological functions they depend on performing, was central to Jakob von Uexküll in his development of the Umwelt theory (1921, 1928 , 2010). We will treat the question of phenomenal vs. non-phenomenal Umwelt experience in the next section. For now, it suffices to state that according to the Umwelt theory, all conscious animals obviously have phenomena (i.e. phenomenal experience), and so does, arguably, several non-conscious organisms endowed with an Umwelt too, in so far as they have holistic, coherent (rather than non-centralized, distributed) subjective experience. In von Uexküll's view, plants and fungi, organisms that are not endowed with any Umwelt, make use of signs in a way that constitute what he calls 'Wohnhüllen', which we could tentatively translate to English as "dwelling enclosures" (cf. von Uexküll 2010: 146-150 (Theory of Meaning), where the term is translated as 'dwelling-shells' or 'dwelling worlds'), a sort of quasi-subjective worlds where "experienced" (i.e. interpreted) meaning is distributed rather than centralized. These "plant worlds" of meaning (etc.) do in our view not involve any phenomenal experience, but they do involve sign exchange (phytosemiosis) of a non-phenomenal nature. 
As one of us have argued (Tønnessen 2015: 361), "it makes sense to propagate a variant of phenomenology under the label 'Uexküllian'", among other things because "Uexküll's call for a subjective biology echoes Husserl's call for a return to the things themselves in the most meaningful way possible, by in effect implying a return to the study and perception of nature qua individuals, nature qua living creatures." Uexküllian phenomenology, in this view, is characterized by an assumption of the widespread occurrence in nature of a genuine first-person perspective, i.e. of experienced worlds (ibid, 362 - somewhat modified here). Built around such a premise, Uexküllian phenomenology represents an original position within phenomenology characterized by recognition of a multitude of different experienced worlds and phenomena.

Husserl's phenomenological theory and von Uexküll's Umwelt theory were developed around the same time, and they have common Kantian roots. In each their way, Husserl and von Uexküll sought to develop Kant's thoughts about transcendental subjectivism further, Husserl towards further applications of the transcendental approach in the realm of human experience, von Uexküll towards animal subjectivity. Drawing on the work of Immanuel Kant, von Uexküll refers to the "phenomenal worlds" ('Erscheinungswelten') that we live in and through. His Umwelt theory is in effect a biological theory that aims to explain how it is that (many) animals too have phenomenal worlds, and how these differ from species to species and from one individual to another.

Philosopher Helmuth Plessner was probably the first to characterize von Uexküll's Umwelt theory as phenomenological - in 1928 he wrote that von Uexküll's scientific project was to offer a "phenomenology of living behaviour" in animals (Plessner 1975 [1928]: 63, our translation). ${ }^{1}$ Some phenomenologists with an ecological orientation, such as David Abram (1996, 2010), hold some related views, as reflected in Abram's consistent interest in multi-species environments and the animal's perspective. A classical phenomenologist many biosemioticians can relate to, namely Maurice Merleau-Ponty (1962 [1945]), explicitly discussed von Uexküll's work (Merleau-Ponty 2003), and stressed the importance of investigating bodily aspects and expressions of subjective experience. Heidegger (1995) as well referred to von Uexküll's work, though only to point out that unlike human beings, animals were in his view "poor in world" (cf. also Buchanan 2008, where von Uexküll's influence on Heidegger, Merleau-Ponty and yet another central philosopher, Gilles Deleuze, is discussed).

Despite the generally anthropocentric orientation of his phenomenology, Husserl himself did occasionally indicate that some non-human animals might have phenomenal experience too. In one of the appendices of The crisis of European sciences and transcendental phenomenology (Husserl 1970, cf. Husserl 1954), he refers to a new attitude "toward men and animals not as bodies to be investigated consistently and descriptively in the attitude oriented towards nature but as men (or animals) who have their bodies as living bodies, who have their personal surrounding world [Umwelt], oriented around their living bodies as the near-far world" (Husserl 1970: 331). And in the main body of text of the book, he writes that

man (and everything else that is real in animal form) is, after all, something real having two strata and is given as such in pure experience, purely in the life-world

\footnotetext{
${ }^{1}$ We thank Carlo Brentari, who reviewed this editorial, for drawing our attention to this point and Husserl and Uexküll's common Kantian roots.
} 
[Lebenswelt] [...] The individual psychology must, then, be the foundation for a sociology and likewise for a science of objectified spirit (of cultural things), which after all refers, in its own way, to the human being as person, i.e., to the life of the soul. And all this can be applied by analogy - just as far as the analogy reaches - to animals, to animal society, to the surrounding world [Umwelt] with its specifically animal signification. (Husserl 1970: 238, emphasis added)

As we see in this last quote, the notions of 'Lebenswelt' and 'Umwelt' can be said to overlap. The methodical difference between the notions boils down to different starting points: The human lifeworld for Husserl vs. a generic animal lifeworld for von Uexküll.

\section{What Is the Relation Between Signs and Phenomena?}

In line with Jakob von Uexküll's thinking, we acknowledge that all Umwelt experience, whether it is of a phenomenal nature or not, is sign-based (and that even organisms that are not endowed with an Umwelt relate to their environment in a sign-based manner). Experiencing phenomena, in our view, presupposes being endowed with a mind, which entails having holistic, coherent subjective experience. This implies that not all Umwelt experience has the form of phenomena. Accordingly, we must distinguish between phenomenal Umwelt experience - in the case of organisms endowed with mind - and nonphenomenal Umwelt experience, in the case of simpler organisms endowed with an Umwelt. While the tick has phenomena, in this sense, a bacterium does not - though it does have a very simple Umwelt-like non-phenomenal representation of the outside world.

In biosemiotics, signals are not opposed to signs but viewed as primitive signs (in the evolutionary sense) or proto-signs. Bacteria are capable of receiving and emitting signals (e.g., molecules for "quorum sensing"), but not of relating to objects that are the sources of received signals. Signals are used to initiate or modify activities directly, without any mental interpretation. But processing of signals in bacteria is not deterministic, because signal transduction is handled by biomechanisms (e.g., proteins) which are meaningful products of the adaptive evolutionary process. Bacterial cells therefore represent an example of semiosis without mind, or proto-semiosis (Sharov and Vehkavaara 2015).

As Jordan Zlatev correctly observes (2009: 170), "for biosemiotics life and "signs" are considered co-extensional and primary to consciousness" - while consciousness as well is understood as being sign-based. A logical consequence of this is to adopt the position that phenomena are special cases of signs, but that there are furthermore nonphenomenal signs, as found e.g. in endosemiosis (somatic sign exchange, e.g. molecular signaling within cells), some of which underpins conscious experience. Treating phenomena as signs means acknowledging that for something to qualify as a phenomenon, it must belong to some group or type of related "phenomena", otherwise it would not be recognizable as phenomena for an organism (this corresponds to a token-type relationship in Peircean semiotics).

Given the core idea of biosemiotics as referred above, which implies that conscious experience is sign-based, it would be nonsensical to suggest that signs are always distinct from phenomena. It does likewise not make sense, from a biosemiotic point of view, to say that there are non-semiotic phenomena, since in a biosemiotic 
understanding all phenomena are sign-based. It is true enough that there are things or events in the world that are not of a semiotic character (say, atomic or molecular rearrangements that are not perceived by any living agent). But just as such things or events would not qualify as being sign-based, nor would they qualify as phenomena, if by that we mean something that appears in experience.

Nevertheless, some semioticians think that there are non-semiotic phenomena, and that signs are special cases of phenomena, rather than the other way around. This perspective is the one that is in effect adopted by both Husserl, and Zlatev, an accomplished and skillful representative of cognitive semiotics. In agreement with Husserl, Zlatev holds that the phenomenological threshold is lower than the semiotic threshold, and hence that there are non-semiotic phenomena. In his perspective (2009: 181), "in agreement with biosemiotics, [...] meaning is seen to be co-extensional with life", but animal Umwelten are seen as being meaningful in terms of "biological value" only, without any acknowledgement of organisms as experiencing subjects. The Umwelt, in Zlatev's understanding, involves nothing but non-phenomenal experience, whereas only more cognitively advanced Umwelt-endowed organisms can be said to have phenomenal experience, and thus relate to phenomena. In this view only an even narrower group of organisms, notably human beings but also certain primates, relate to signs.

Husserl held that phenomenology envelops all the phenomena of mind. Biosemioticians tend to have a considerably wider notion of mind than Husserlians (for a review of a biosemiotic understanding of a related phenomenon, intentionality, see Favareau and Gare 2017). A strictly Husserlian concept of mind is much too narrow to capture all biosemiotic phenomena, many of which will fall outside of the scope of phenomenology with such a conception.

As John Deely observes (2014: 11), Jakob von Uexküll's development of the Umwelt notion (von Uexküll 1921, 1928, 2010) "defines a cross-road where the" development of phenomenology and semiotics "unmistakably intersect". The theoretical description of the connection between signs and phenomena is most developed in his last major work, Bedeutungslehre (translated to English as Theory of meaning, cf. von Uexküll 2010). Here von Uexküll explains how phenomena, our coherent experience of objects and events in our Umwelt, are always underpinned by perceptual signs ('Merkzeichen'), and how our actions are always underpinned by action-related signs ('Wirkzeichen').

\section{Should Biosemiotic Phenomenology Be Pure Theory, or Applicable for Empirical Studies?}

When phenomenology is approached as pure theory first and last - as it is by some scholars, particularly philosophers - this philosophical investigation of "what appears" is fashioned to be so remote from empirical studies that it can have no perceptible relevance whatsoever for researchers in the empirical sciences. In order to be relevant for science at large, phenomenologists need to interact with empirical researchers, and engage with real-life problems.

Broadly speaking, contemporary phenomenology is divided into two camps, where one is theoretically inclined and the other has a practical orientation. Phrased differently, one camp focuses almost exclusively on phenomenology as a philosophical theory, while the other focuses on phenomenology's utility as a method for 
studying experiences. This said, a random specimen of the class "phenomenologist" might in several cases balance theory and empirical investigations in a mutually informed manner.

The starting point for Umwelt theory is that it was, from von Uexküll's side, meant as a perspective to apply in empirical studies, first and foremost within biology. This should speak for giving Biosemiotic Phenomenology, i.e. phenomenology informed by Umwelt theory and other biosemiotic work, an applied orientation. As phenomenologist and biosemiotician Maurita Harney (2015) and several other argues, naturalizing phenomenology makes it more relevant and applicable. In this endeavor, biosemiotic studies with applied aspects and elements of Umwelt theory can serve as an ally.

Some biosemioticians who largely base their thinking on the work of Peirce (19311958) might conclude differently. Peirce is known for having coined the term 'phenomenology' at about the same time as Husserl (see Spiegelberg 1956), before abandoning the term in favor of the more obscure 'Phaneroscopy'. With Peirce's understanding of phenomenology, phenomenology is to be understood in terms of pure theory, since it intends to describe phenomena generally and not specifically in all their empirical diversity (cf. Tønnessen 2011). With such a conception, phenomenology is destined to remain a purely theoretical enterprise. However, luckily most Peircean biosemioticians have more empirical inclinations in this respect.

\section{How Biosemiotics Can Contribute to Phenomenology}

Jakob von Uexküll's classical, original version of Umwelt theory is sometimes seen as a perspective on - or approach to - biology that is first and foremost of historical interest. Von Uexküll's work no doubt contributed significantly to theoretical biology. As a source of inspiration for biosemiotics and related schools of thought, however, the Umwelt theory should also be understood as a dynamical theory that is ripe for updating and application on current matters (Brentari 2015). In contemporary times, the biosemiotics community is one of the most prominent advocates of the Umwelt theory. If it is true, as we have indicated above, that Umwelt theory represents a genuine perspective within phenomenology, then it appears that biosemiotics is well positioned to contribute valuably to the development of phenomenology.

The key to biosemiotics' possible contribution to phenomenology is related to the way in which applied phenomenology can take the form of applied Umwelt theory. This would make phenomenological analysis, in form of Biosemiotic Phenomenology, available not only for studies of human experience, but furthermore for studies of animal experience, and human-animal relations. From a theoretical point of view, Umwelt theory challenges central dogmas in current phenomenology, starting with the misguided idea that all phenomena are human phenomena.

Generally, a semiotic understanding of phenomena can help us to understand how meaning comes to be by way of a study of sign processes. The more specifically biosemiotic contribution to phenomenology derives from its basis in empirical science and its more-than-human (Abram 1996) perspective. Applying a biosemiotic outlook in phenomenology equips us to study and understand the subjective worlds of individual animals, and the role that species-specific and individual experience of meaning plays in complex ecological wholes. A biosemiotically informed phenomenology is 
particularly suitable for studies of multi-species environments involving human-animal relations that can potentially be analyzed from multiple perspectives.

But it does more than this. By understanding animal experience, as distinguished from human experience, we can arrive at a more informed understanding of genuinely unique human experience. Ironically, an excessively anthropocentric scholar who dismisses the significance of studying animal experience in favor of focusing solely on human experience, will inevitably end up understanding both kinds of experience less than optimally. He/she will understand animal experience poorly, because he/she does not study it, and he/she will understand human experience poorly, because he/she studies it as if it were the only kind of experience, thus being ignorant of what is truly unique to humans.

One of the simpler lessons semiotics has to offer, is this: Context matters. And the context of human experience - in a word, nature - involves a multitude of other species' experiences. This is the case whether we take on an evolutionary, long-term perspective on current human experience, or a contemporary perspective focused on human ecology. To understand current global ecology, we must study humans, for we live in a world dominated by anthropogenic environmental change. Likewise, to understand humans, we must study animals, for we live in a more-than-human world.

\section{References}

Abram, D. (1996). The spell of the sensuous: Perception and language in a more-than-human world. New York: Vintage Books.

Abram, D. (2010). The discourse of the birds. Biosemiotics 3(3): 263-275. Excerpt from D. Abram (2010): Becoming animal: An earthly cosmology. New York: Pantheon.

Brentari, C. (2015). Jakob Von Uexküll: The discovery of the Umwelt between biosemiotics and theoretical biology (Biosemiotics 9). Springer.

Buchanan, B. (2008). Onto-ethologies: The animal environments of Uexküll, Heidegger, Merleau-Ponty, and Deleuze. Albany: SUNY Press.

Deely, J. (2014). Semiotic entanglement: the concepts of environment, Umwelt, and Lebenswelt in semiotic perspective. Semiotica, 199, 7-42.

Favareau, D., \& Gare, A. (2017). The biosemiotic glossary project: intentionality. Biosemiotics, 10(3), 413-459.

Harney, M. (2015). Naturalizing phenomenology - a philosophical imperative. Progress in Biophysics and Molecular Biology, 119(3), 661-669.

Heidegger, M. (1995). The fundamental concepts of metaphysics: World, finitude, solitude. Bloomington: Indiana University Press.

Hoffmeyer, J. (2008). Biosemiotics: an examination into the signs of life and the life of signs. Scranton: University of Scranton Press.

Husserl, E. (1900). Logische Untersuchungen. Erste Teil: Prolegomena zur reinen Logik. Halle.

Husserl, E. (1901). Logische Untersuchungen. Zweite Teil: Untersuchungen zur Phänomenologie und Theorie der Erkenntnis. Halle.

Husserl, E. (1954). Die Krisis der europaischen Wissenschaften und die Tranzendentale Phänomenologie (Husserliana: Gesammelte Werke 6). Haag: Martin Nijhoff.

Husserl, E. (1970). The crisis of European sciences and transcendental phenomenology: An introduction to phenomenological philosophy. Transl. of and selection from Husserl 1954 by D. Carr. Evanston: Northwestern University Press.

Lowland, P., Panksepp, J., Reiss, D, Edelman, D., van Swinderen, B., Low, P. \& Koch, C. (2012). The Cambridge declaration on consciousness. URL: http://fcmconference.org/img/CambridgeDeclarationOnConsciousness.pdf. University of Cambridge.

Merleau-Ponty, M. (1962 [1945]). Phenomenology of perception (trans: Smith, Colin). London: Routledge \& Kegan Paul. 
Merleau-Ponty, M. (2003). Nature. Compiled by D. Séglard, transl. by R. Vallier. Evanston: Northwestern University Press.

Peirce, C. S. (1931-1958). Collected papers of Charles Sanders Peirce. 8 volumes. Vols. 1-6, eds. C. Hartshorne and P. Weiss, vols. 7-8, ed. A.W. Burks. Cambridge: Harvard University Press.

Plessner, H. (1975 [1928]). Die Stufen des Organischen und der Mensch. New York: Walter de Gruyter.

Sharov, A., \& Vehkavaara, T. (2015). Protosemiosis: agency with reduced representation capacity. Biosemiotics, 8(1), 103-123.

Spiegelberg, H. (1956). Husserl's and Peirce's phenomenologies: coincidence or interaction. Philosophy and Phenomenological Research, XVII(1), 164-185.

Spiegelberg, H. (1982). The phenomenological movement: A historical introduction (3rd rev. \& enlarged ed. with the collaboration of K. Schuhmann). The Hague/Boston/London: Martinus Nijhoff Publishers.

Tønnessen, M. (2011). Semiotics of being and Uexküllian phenomenology. In A.-T. Tymieniecka (Ed.), Phenomenology/Ontopoiesis retrieving geo-cosmic horizons of Antiquity (= Analecta Husserliana CX/ 110) (pp. 327-340). Dordrecht: Springer.

Tønnessen, M. (2015). Uexküllian phenomenology. Chinese Semiotic Studies, 11(3), 347-369. https://doi. org/10.1515/css-2015-0018).

von Uexküll, J. (1921). Umwelt und Innenwelt der Tiere (2nd ed.). Berlin: Verlag von Julius Springer.

von Uexküll, J. (1928). Theoretische Biologie (2nd ed.). Berlin: J. Springer.

von Uexküll, J. (2010). A Foray into the Worlds of Animals and Humans with A Theory of Meaning (Posthumanities 12). Transl. by J. D. O’Neil. Minneapolis \& London: University of Minnesota Press.

Weber, A. (2002). Feeling the signs: the origins of meaning in the biological philosophy of Susanne K. Langer and Hans Jonas. Sign Systems Studies, 30(1), 183-199.

Westling, L. (2014). The logos of the living world: Merleau-Ponty, animals, and language. New York: Fordham University Press.

Zahavi, D. (2006). Does (Husserlian) phenomenology have a future? Internet project organized by the Husserl Archives at the New School for Social Research. URL: http://www.newschool. edu/nssr/husserl/Future/Part\%20Two/Zahavi.html

Zlatev, J. (2009). The semiotic hierarchy: Life, consciousness, signs and language. Cognitive Semiotics, 4, 169-200. 